\title{
Formulation, Evaluation and Anti-Hemorroidal Activity of Suppositories Containing Moringa Oleifera Lam. Seed Oil
}

\author{
Christianah Y. Isimi ${ }^{*}$, Lucy B. John-Africa ${ }^{2}$, Kokonne E. Ekere ${ }^{1}$, Olubunmi J. Olayemi', \\ Olusola I. Aremu ${ }^{3}$, Martins 0. Emeje ${ }^{1,4}$ \\ 1 Department of Pharmaceutical Technology and Raw Materials Development, National Institute for Pharmaceutical Research and \\ Development, Abuja, Nigeria \\ 2 Department of Pharmacology and Toxicology, National Institute for Pharmaceutical Research and Development, Abuja, Nigeria \\ 3 Department of Pharmaceutics and Industrial Pharmacy, Faculty of Pharmaceutical Sciences, University of Ilorin, Nigeria \\ 4 Centre for Nanomedicine and Biophysical Drug Delivery, National Institute for Pharmaceutical Research and Development, \\ Abuja, Nigeria
}

\section{ABSTRACT}

The plant Moringa oleifera has been reported to have various ethnomedicinal uses, of particular interest is the anti-inflammatory effect of the seed oil. In this study, suppository formulations containing Moringa seed oil (MSO) were developed for the management of inflammatory conditions of the anorectal region. The suppositories were prepared using a water soluble base, macrogol (MG) and a fatty base, dika fat (DF), obtained from Irvingia gabonensis seeds; they were evaluated for appearance, hardness, weight variation, melting point, $\mathrm{pH}$, liquefaction time and in vitro release according to standard pharmacopoeia procedures. Anti-hemorroidal activity of the formulations in laboratory rats were also evaluated. Results show that all the suppositories prepared had good physicochemical properties. In vivo studies revealed that the optimized preparation containing dika fat was effective in reducing hemorrhoids induced in rats. Therefore, this study demonstrates the propensity of Moringa seed oil suppositories in the treatment of anorectal inflammatory conditions.

Keywords: Moringa seed oil; suppositories; Dika fat; Macrogol; Anti-inflammatory.

Corresponding author:

Department of Pharmaceutical Technology and Raw Materials Development, National Institute for Pharmaceutical

Research and Development, Abuja, Nigeria.

Telephone number: +2348033156606

E-mail address: yetsimi@yahoo.com

ORCID

Christianah Isimi 0000-0002-9066-9984,

Lucy John-Africa 0000-0002-2771-0526,

Kokonne Ekere 0000-0001-8876-9284,

Olubunmi Olayemi 0000-0001-5759-7176,

Olusola Aremu 0000-0002-3890-1256,

Martins Emeje 0000-0002-0202-5426

(Received 16 December 2019, accepted 30 April 2020) 


\section{INTRODUCTION}

The plant Moringa oleifera Lam. is a species of the family, Moringaceae; it is native to South Asia (India, Pakistan, Bangladesh and Afghanistan) but has been cultivated in the Philippines and the Sudan, Latin America and Africa (Fahey, 2005). In Nigeria, Moringa oleifera has become naturalized and is popularly known as "Okwe-beke" by the Igbos, "Zogale" by the Hausas, and "Ewe igbale" by the Yorubas) (Evbuomwan, Dick, \& Chioma, 2017).

The plant is called the "miracle tree" because of its action against a wide range of ailments. Preparations of the various parts of the plant have been reported to have antimicrobial, anti-inflammatory, anticancer, hepatoprotective, antioxidant, cardiovascular, antiepileptic, antidiabetic, diuretic, anthelminthic, antiulcer and wound healing activities (Mishral et al., 2011; Amrutia, Lala, Srinivasa, Shabaraya, \& Moses, 2011; Gupta et al., 2012; Rastogi, Bhutda, Moon, \& Aswar, 2009).

The seeds particularly possess constituents that make them useful in the treatment or management of anti-inflammatory diseases (Saini, Sivanesan, \& Keum, 2016), traditionally, the seed oil has been used for the treatment of rheumatism, warts, arthritis, mineral and vitamin deficiency (Fahey, 2005; Mishral et al., 2011). Moringa seed oil can be obtained from the seed kernels using organic solvents like n-hexane; the extracted oil is pale yellow, sweet, non-sticky, non-drying and resistant to rancidity (Olaleye \& Kukwa, 2018; Lalas \& Tsaknis, 2002). This fatty oil contains palmitic, behenic, stearic and arachidic acids as major parts of its fatty acid contents in addition to small traces of cerotic, lignoceric, myristic, margaric, erucic and caprylic acids. The oil also contains oleic acid as the predominant fatty acid i.e. $73.57 \%$ of the total fatty acids and about only $1.2 \%$ polyunsaturated fatty acids (Ogunsina et al., 2014).

Studies have shown the anti-inflammatory properties of Moringa seed oil; Suryadevara, Doppalapudi, Sasudhar, Anne and Mudda (2018) developed a cream formulation using Moringa seed oil and found that the cream reduced carrageenan-induced paw edema by $70 \%$, which was similar to that reported for Ibuprofen. In a similar study by Somnath et al. (2015), microemulsion formulations of Moringa seed oil were also found to reduce carrageenan-induced paw edema for up to $3 \mathrm{~h}$. Another study showed that the hydro-alcoholic extract of $M$. oleifera seeds and its chloroform fraction were able to reduce acetic-acid induced colitis in rats (Minaiyan, Asghari, Taheri, Saeidi, \& Nasr-Esfahani, 2014).

Hemorrhoids are in essence a cluster of tissues and muscles that line the anal canal, but they are inappropriately used as such when these tissues and muscles become swollen or inflamed. Symptoms of "hemorrhoids" include rectal bleeding, 
pain, protrusion and treatment is often initiated by insertion/application of nonsteroidal anti-inflammatory drug products into the rectal region (Perry, 2019). Herbal remedies have also being exploited in the management and treatment of hemorrhoid inflammation (Eshghi et al., 2010; Hamidpour \& Rashan, 2017).

Suppositories are solid bodies of various weights and shapes, adapted for introduction into the rectal, vaginal, or urethral orifice where they melt, soften, or dissolve at body temperature to release the stored drug. They are usually formulated using lipophilic or hydrophilic bases (Goodman, 2001). Incorporation of Moringa oil in this dosage form could be used in managing such diseases like "hemorrhoids".

Therefore, the aim of this study was to formulate oil extracted from Moringa seeds into suppositories using water soluble base; macrogol (MG) and fatty base; dika fat (DF) and to investigate the anti-hemorroidal activity in laboratory rats.

\section{METHODOLOGY}

Plant materials used include Moringa oleifera and Irvingia gabonensis seeds. Other materials used were liquid paraffin, Polyethylene glycol 1000 \& 4000 (Emprove EXP, Merck Germany), Petroleum ether (Loba chemie, India), Sodium hydroxide, Hydrochloric acid and Sodium dihydrogen orthophosphate (Analar, Germany), Nutrient Agar (Sigma Life Sciences, USA), Ferric chloride (Sigma Aldrich, USA) and Distilled and Deionised water (National Institute for Pharmaceutical Research and Development Laboratory, NIPRD, Abuja, Nigeria).

\section{Animals}

Adult Wistar Albino rats (200 - $240 \mathrm{~g}$ ) were obtained from the Animal Facility Centre (AFC) of the National Institute for Pharmaceutical Research and Development (NIPRD), Abuja. The animals were housed under ambient conditions of temperature $26 \pm 1{ }^{\circ} \mathrm{C}$ and light approximately $12 / 12 \mathrm{~h}$ light/dark cycle. They were fed on standard rodent diet with free access to clean drinking water from the Municipal water system. The experiments were carried out on animals handled according to the Institutional Animal Ethical committee guideline as reflected in the Institutional SOP No 05:003.

\section{Extraction}

Extraction of dika fat from Irvingia gabonensis seeds

Irvingia gabonensis seeds were purchased from Karmo market, Abuja, Nigeria. They were validated at the herbarium section of the National Institute for Pharmaceutical Research and Development (NIPRD), Abuja where a voucher sample (NIPRD/H/6983) was obtained. The seeds were milled and $490 \mathrm{~g}$ of the pulve- 
rized seed was weighed (Mettler Toledo, Switzerland), and then macerated with petroleum ether at a ratio of 1 to 5 . The mixture was left for about $72 \mathrm{~h}$ after which the supernatant was decanted, filtered and concentrated over a water bath (Karl Kobb, Derieich West Germany) at about $100{ }^{\circ} \mathrm{C}$. The resulting extract was weighed and kept at room temperature until further use.

\section{Extraction of oil from Moringa oleifera seeds}

Moringa oleifera seeds were obtained from the medicinal garden of the National Institute for Pharmaceutical Research and Development, NIPRD, Abuja. It was identified at the herbarium and a voucher number NIPRD/H/7078 was obtained. A quantity of $300 \mathrm{~g}$ of seed was pulverized using a blender (Qlick, Japan) and used for the continuous soxhlet extraction using petroleum ether in the ratio of 1 to 5 at $60{ }^{\circ} \mathrm{C}$. The oil obtained was heated on a water bath (Karl Kobb, Derieich West Germany) at about $100{ }^{\circ} \mathrm{C}$ to evaporate the residual solvent. The extracted oil (MSO) was weighed, packaged in a sterile container and stored at room temperature.

\section{Preparation of MSO suppositories using different bases}

Pour moulding method was used for the manufacture of the suppositories in precalibrated mould with different bases. Calculated displacement values were used in defining the various final quantities of the bases used. The suppository mould was properly cleaned and lubricated with liquid paraffin. Appropriate quantities of bases and MSO as presented in Table 1 were put into a beaker and allowed to melt at $60{ }^{\circ} \mathrm{C}$ on a water bath (Karl Kobb, Derieich West Germany). In the case of macrogol base, an emulsion was initially formed based on required HydrophilicLipophilic Balance (HLB) of MSO, 12. The mixtures were vigorously stirred together at about $50{ }^{\circ} \mathrm{C}$ using a magnetic stirrer (VWR Company, Germany) to allow for homogenous mixture. The mixture was poured into the mould until it overflowed; it was re-filled as the solidifying mixture was shrinking. The mould content was allowed to solidify, the suppositories were thereafter removed and packaged in aluminum foil until further evaluations were conducted. This procedure was repeated for production of placebo suppositories as control formulations.

\section{Preparation of suppositories for animal studies}

For the animal studies, $0.3 \mathrm{~g}$ of $5 \%$ and $10 \%$ MSO suppositories were prepared, this was done to adjust to the anatomic size of the rats. 
Table 1: Composition of suppository formulations

\begin{tabular}{ccccccc}
\hline Ingredients & MSD1(g) & MSD2(g) & MSDO(g) & MSM1(g) & MSM2(g) & MSMO(g) \\
\hline Moringa seed oil & 5 & 10 & - & 5 & 10 & - \\
Tween 80 & - & - & - & 4.22 & 4.74 & - \\
Span 20 & - & - & - & 0.78 & 0.26 & - \\
\hline $\begin{array}{c}\text { PEG 1000 80 \% + PEG } \\
400020 \%) \text { to }\end{array}$ & - & - & - & 98.4 & 98.4 & 98.4 \\
Dika fat to & 80.2 & 80.2 & 80.2 & - & - & - \\
\hline
\end{tabular}

MSMo = macrogol base alone, MSM1 $=5 \% \mathrm{w} / \mathrm{w}$ Moringa seed oil + macrogol base, $\mathrm{MSM} 2=10 \% \mathrm{w} / \mathrm{w}$ Moringa seed oil + macrogol base, $\mathrm{MSDo}=$ dika fat base alone, MSD1 $=5 \% \mathrm{w} / \mathrm{w}$ Moringa seed oil + dika fat base, MSD2 $=10 \% \mathrm{w} / \mathrm{w}$ Moringa seed oil + dika fat base.

\section{Evaluation of Suppositories}

\section{Appearance}

Six suppositories were randomly selected from each group including placebo and they were observed as an intact unit and also after splitting them longitudinally. Colour, odour, shape, the absence of fissuring, pitting, exudation, sedimentation and the migration of the active ingredients were also assessed.

\section{Weight uniformity}

The weight uniformity test was carried out as designated in the British Pharmacopoeia (BP, 2013). Twenty suppositories were randomly chosen from each batch of the formulations and weighed independently using an analytical balance (Mettler Toledo, Switzerland). The average weights and standard deviations were calculated.

\section{Determination of $\mathrm{pH}$}

The $\mathrm{pH}$ of each melted suppository was determined by a $\mathrm{pH}$ meter (Jenway, UK). All measurements were an average of three measurements and expressed as mean \pm standard deviation.

\section{Hardness/ Crushing Strength}

The crushing strength, a measure of mechanical power or hardness of the sup- 
pository was determined using the hardness tester (Erweka GmbH, Germany). Six suppositories randomly selected from each batch were used for the measurement. The weight at which each suppository cracked was documented in Kilogram force and converted to Newton.

\section{Liquefaction Time}

Six suppositories were indiscriminately chosen from each lot for this test. Thereafter, $60 \mathrm{~mL}$ of phosphate buffer with a pH of 7.4 was heated up to $37 \pm 1^{\circ} \mathrm{C}$ and maintained. Each suppository was dropped inside the buffer and the time taken for the suppository to completely dissolve or melt was noted as the liquefaction time.

\section{Melting point Determination}

The melting point of MSO suppositories were determined according to the technique of Adebayo and Akala (2005). A suppository randomly selected from each batch was put in a beaker with a thermometer introduced. The beaker was immersed in a water bath (Karl Kobb, Derieich West Germany) at about $6 \mathrm{~cm}$ depth, controlled to a steady temperature rise of $1^{\circ} \mathrm{C} / 2 \mathrm{~min}$. The temperature at which the suppository sample began to melt was taken as the melting point. The outcome was an average of five determinations. The melting point of the placebo was also determined in a similar fashion.

\section{In-vitro release}

The release of MSO from suppository bases was determined using agar diffusion method (Aremu et al., 2019). A quantity of $0.25 \mathrm{~mL}$ of melted suppository was measured into a $25 \mathrm{~mL}$ volumetric flask and made up to $25 \mathrm{~mL}$ with phosphate buffer, then mixed thoroughly. Sterilized nutrient agar was poured into a plate and left to solidify, the surface of each plate was flooded with a dye and the extra solution was drained off. Two holes were bored in these plates using a $6 \mathrm{~mm}$ cork borer, and $0.5 \mathrm{~mL}$ of $\mathrm{o} \%, 5 \%$ and $10 \% \mathrm{w} / \mathrm{w}$ of MG and DF formulated suppositories were respectively placed in the holes. The plates were then placed on a laboratory bench for 1 hour for diffusion to occur before being transferred to the incubator (Karl Kobb, Derieich West Germany) at $37^{\circ} \mathrm{C}$. The zones of colour change were measured for each sample at time intervals of $1 \mathrm{~h}, 2 \mathrm{~h}, 3 \mathrm{~h}$ and $12 \mathrm{~h}$.

\section{Fourier-transform infrared spectroscopy (FTIR)}

The method of Kauss et al. (2013) was adopted in preparation of the pellets. The suppositories were ground, triturated with potassium bromide and compressed into pellets. Infra-red spectra were obtained from the impact 410 Nicolet FTIR spectrometer (Thermo fisher Scientific, USA) between frequency range of 4000 and $650 \mathrm{~cm}^{-1}$. 


\section{Gas chromatography-mass spectrometry (GC-MS)}

The method of Okhale et al. (2018) was adopted. Each component was recognized by matching their mass spectra with known compounds and NIST Mass Spectral Library (NIST 11).

\section{Animals}

Adult Wistar Albino rats (200 - 240g) were obtained from the Animal Facility Centre (AFC) of the National Institute for Pharmaceutical Research and Development (NIPRD) Idu, Abuja. The animals were housed under ambient conditions of temperature $26 \pm 1{ }^{\circ} \mathrm{C}$ and light approximately $12 / 12 \mathrm{~h} \mathrm{light} /$ dark cycle. They were fed on standard rodent diet with free access to clean drinking water from the $\mathrm{Mu}$ nicipal water system. Ethical permission for the study was obtained from NIPRD Animal Care and Ethics (NIPRD/05:3:05-03) in line with International Guiding Principles for Biomedical Research involving animals (CIOMS/ICLAS, 2012).

\section{Studies on croton oil induced haemorrhoids in Wistar Albino rats}

Twenty-five overnight fasted rats were randomly placed into 5 groups of 5 animals each. Group 1 served as the sham group. Hemorrhoids were induced in animals in group $2-5$. The hemorrhoid inducing agent was prepared using deionized water, pyridine, diethyl ether, and $6 \%$ croton oil in diethylether in the ratio of 1:4:5:10. The inducing agent $(0.16 \mathrm{~mL})$ was dropped onto sterile cotton swab of 4 $\mathrm{mm}$ diameter and was carefully inserted through the anal opening up to a length of $20 \mathrm{~mm}$. This was held in place for 10 seconds after which the cotton swab was removed. Twenty-four hours after induction, animals were treated as follows: Group 2 served as negative control and received no treatment, group 3 was treated with the suppository (o \% MSO), group 4 received suppository with $5 \%$ Moringa seed oil, while group 5 was administered 10 \% Moringa seed oil suppository. The suppositories were administered daily for 5 days. Twenty-four hours after administration of the last dose, the animals were euthanized by diethyl ether inhalation. Thereafter, the distal $2 \mathrm{~cm}$ of the anal region was isolated and weighed on a digital balance (Mettler Toledo - SNR 1113092341). The tissues were subsequently preserved in $10 \%$ buffered formaldehyde solution for histological examination (Nishiki, Nishinaga, Kudoh, \& Iwai, 1988; Azeemuddin et al., 2014).

Recto-anal Coefficient (RAC) was calculated using the formula:

$$
\text { Recto-anal Coefficient }=\frac{\text { Weight of Recto-anal tissue (mg) }}{\text { Weight of animal }(\mathrm{g})}
$$




\section{Statistical analysis}

Values are presented as Mean \pm SEM and analyzed by one-way ANOVA followed by Dunnet's post Hoc test. Level of significance was set at $\mathrm{p}<0.05$.

\section{RESULTS AND DISCUSSION}

Table 2. Physicochemical properties of Moringa seed oil suppositories

\begin{tabular}{ccccccc}
\hline Parameters & MSM1 & MSM2 & MSD1 & MSD2 & MSM0 & MSD0 \\
\hline Shape & Torpedo & Torpedo & Torpedo & Torpedo & Torpedo & Torpedo \\
Colour & White & Off-White & Milky & Cream & White & $\begin{array}{c}\text { Light- } \\
\text { Yellow }\end{array}$ \\
$\begin{array}{c}\text { Mean Weight } \\
\text { (g) }\end{array}$ & $2.39 \pm 0.02$ & $2.32 \pm 0.02$ & $1.97 \pm 0.07$ & $2.02 \pm 0.01$ & $2.39 \pm 0.02$ & $2.32 \pm 0.01$ \\
$\begin{array}{c}\text { Melting Point } \\
\text { ( } \mathbf{C} \text { ) }\end{array}$ & $36.17 \pm 0.49$ & $36.73 \pm 0.59$ & $31.53 \pm 0.15$ & $31.80 \pm 0.15$ & $37.43 \pm 0.45$ & $32.27 \pm 0.21$ \\
$\begin{array}{c}\text { Hardness (N) } \\
\begin{array}{c}\text { Liquefaction } \\
\text { time (min) }\end{array}\end{array}$ & $19.6 \pm 2.0$ & $13.7 \pm 2.0$ & $12.3 \pm 0.3$ & $10.7 \pm 1.1$ & $22.2 \pm 1.1$ & $16.0 \pm 1.1$ \\
$\begin{array}{c}\text { Displacement } \\
\text { value }\end{array}$ & 0.65 & - & 0.74 & - & - & - \\
Ph & $6.37 \pm 0.01$ & $6.67 \pm 0.02$ & $5.12 \pm 0.01$ & $5.20 \pm 0.15$ & $5.97 \pm 0.09$ & $5.08 \pm 0.03$ \\
\hline
\end{tabular}

MSMo $=$ macrogol base alone, MSM1 $=5 \% \mathrm{w} / \mathrm{w}$ Moringa seed oil + macrogol base, MSM2 = $10 \% \mathrm{w} / \mathrm{w}$ Moringa seed oil + macrogol base, MSDo = dika fat base alone, MSD1 $=5 \% \mathrm{w} / \mathrm{w}$ Moringa seed oil + dika fat base, MSD2 $=10 \% \mathrm{w} / \mathrm{w}$ Moringa seed oil + dika fat base.

The rate at which the active ingredient is released from the suppository is shown in Figure 1 


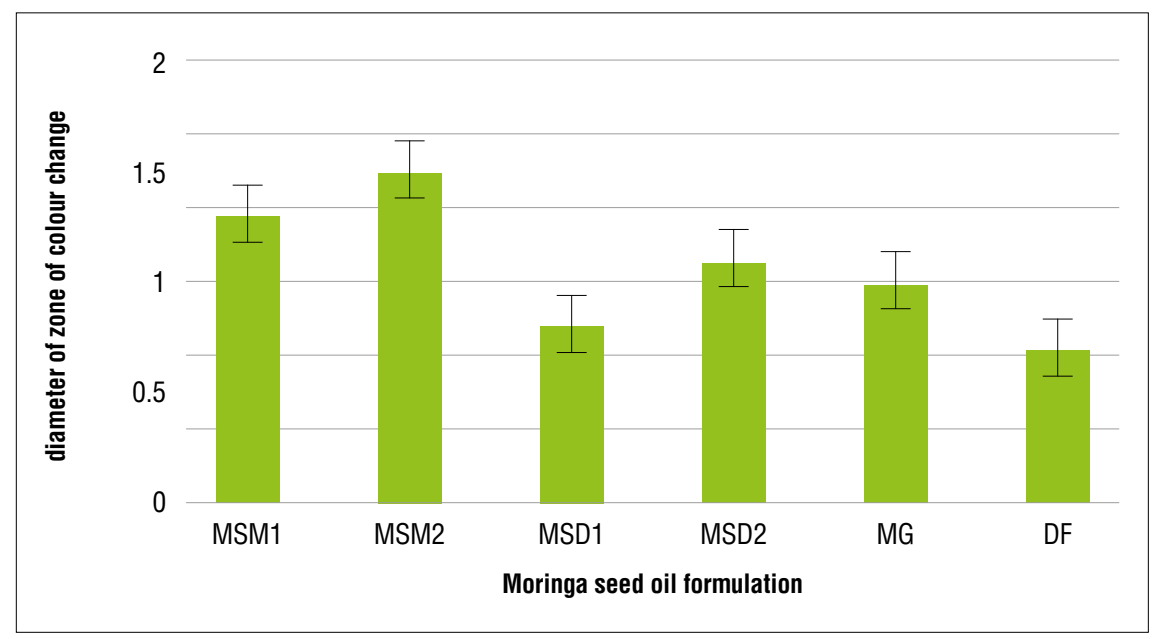

Figure 1. Average diameter of zone of colour change for prepared suppositories

Table 3. Effects of Moringa Oil suppository on Recto-anal Coefficient

\begin{tabular}{|c|c|c|}
\hline Group & Treatment & Recto-anal coefficient \\
\hline $\mathbf{1}$ & Sham & $1.94 \pm 0.15^{\mathrm{c}}$ \\
\hline $\mathbf{2}$ & Control & $3.50 \pm 0.30$ \\
\hline $\mathbf{3}$ & MSD0 & $3.20 \pm 0.17$ \\
\hline $\mathbf{4}$ & MSD1 & $2.26 \pm 0.17^{\mathrm{b}}$ \\
\hline $\mathbf{5}$ & MSD2 & $2.05 \pm 0.38^{\mathrm{b}}$ \\
\hline
\end{tabular}

Values are presented as Mean $\pm \operatorname{SEM}(n=5)$,

Significance compared to control, ${ }^{\mathrm{b}} \mathrm{p}<0.01,{ }^{\mathrm{c}} \mathrm{O} .001$ groups (One-way ANOVA, Dunnet's Post Hoc)

The extraction yield of of dika fat from the seeds was $40.16 \% \mathrm{w} / \mathrm{w}$ while that of Moringa oil was $24 \% \mathrm{w} / \mathrm{w}$. This value is lower than already reported (Efeovbokhan, Hymore, Raj, \& Sanni, 2015; Eman \& Muhamad, 2016; Siyanbola et al., 2015) and could be attributed to the difference in extraction solvents used. Dika fat (DF) was light yellow with its characteristic odour, Moringa seed oil (MSO) was pale yellow but with a characteristic peanut odour.

When the suppositories were split longitudinally, it was observed that there was absence of fissures, the suppositories were stable and had uniform colour. There 
was also absence of sedimentation and exudation indicating uniform suppository mix. All the suppositories had uniform weight; not deviating from the average by more than $5 \%$ as specified by the British pharmacopeia (BP, 2013). This indicates that the pouring of the suppository mixture into the mould was accurately done. Uniformity of weight is of importance in the formulation of drugs as it ensures that the required osr specified amount of drug reaches the site of action.

Hardness/crushing strength is a key parameter assessed in pharmaceutical formulations as it indicates the degree to which a particular formulation resists mechanical wear and tear during handling and transportation. The results of the crushing strength of the placebo in order of their strengths were MSMo (22.2 \pm 1.1$)$ $>\operatorname{MSDo}(16.0 \pm 1.1 \mathrm{~N})$ while those containing medicaments were MSM1 (19.60 $\pm 2.0)>\operatorname{MSM} 2(13.70 \pm 2.0 \mathrm{~N})>\operatorname{MSD} 1(12.30 \pm 0.3)>\operatorname{MSD} 2(10.70 \pm 1.1 \mathrm{~N})$. Generally, hardness/crushing strength of suppositories should be at least 1.8-2 $\mathrm{kg}$ pressure; it was observed that suppositories without Moringa seed oil (MSO) were stronger than those containing the incorporation of the MSO. Based on this, the suppositories with the macrogol base can be said to stand a better chance of withstanding rigorous handling and other mechanical conditions.

The $\mathrm{pH}$ of a pharmaceutical preparation is not to be neglected as it indicates compatibility of the preparation with the site of action. The $\mathrm{pH}$ of the macrogol based suppositories was similar to that of the rectum which is between 6 and 8, while the dika fat based suppositories had a slightly acidic $\mathrm{pH}$ (5.12- 5.20), which may likely irritate the rectal mucosa.

One of the most important characteristics of suppository bases is stability at room temperature, that is, it should not melt at room temperature but melt or dissolve at body temperature in order to release the active ingredient. Generally, the melting point should be less than or equal to $37^{\circ} \mathrm{C}$. It can be observed that the inclusion of the Moringa seed oil reduced the melting point of the suppositories. The melting point of the suppositories in increasing order are MSM2 (36.73 \pm 0.59$)>$ MSM1 (36.17 \pm 0.49$)>$ MSD2 (31.80 \pm 0.15$)>$ MSD1 (31.53 \pm 0.15$)$. These values were observed to be lower than the melting point of MSMo and MSDo (suppositories without Moringa seed oil).

The liquefaction time is the time taken for a suppository to melt or dissolve at body temperature. The liquefaction time is a function of the melting point. It is important to note that the liquefaction time of suppositories should take no longer than 3omins (Mosbah \& Mokhtar, 2016). The liquefaction time exhibited by the suppositories was satisfactory except for the MSD1 which had a liquefaction time above 3omins. A suppository which does not melt or dissolve within 3omins 
would take a longer time to elicit its action (Taha, Zaghloul, \& Kassem, 2003).

In the release study carried out, it was observed that the zone of colour change increased with time. The suppositories with macrogol base had a wider zone of colour change compared to suppositories with dika fat. Generally, lipophilic drugs formulated with hydrophilic bases tend to release faster than those formulated with lipophilic bases, which is due to less affinity for the base as seen in this study.

FTIR spectrum of Moringa seed oil (Figure 2) shows prominent peaks at 2922 and $2855 \mathrm{~cm}^{-1}$ which correspond to the assymmetric and symmetric $\mathrm{C}-\mathrm{H}$ bond in the $\mathrm{CH}_{2}$ functional group. These sharp peaks could also be attributed to high lipid contents of the seed. The broadband at around $3004.2 \mathrm{~cm}^{-1} \mathrm{can}$ be due to the $\mathrm{O}-\mathrm{H}$ stretching, in addition, the presence of $\mathrm{N}-\mathrm{H}$ due to amides as a result of high protein content of Moringa seed could also be responsible for the peak observed. Peaks observed at 1744.4 and $1710.8 \mathrm{~cm}^{-1}$ could be attributed to the carbonyl group $(\mathrm{C}=\mathrm{O})$ which is due the lipid portion of the seed. The spectrum for macrogol shows characteristic peaks at 3485.1, 28738, 1464.8, 1341.8, 1099.6 $\mathrm{cm}^{-1}$ indicating the presence of $\mathrm{O}-\mathrm{H}$ and $\mathrm{C}-\mathrm{O}$ functional groups. Dika fat spectrum shows major peaks at $3485.1,2873.8,1341.8,1099.6 \mathrm{~cm}^{-1}$; the broad peak at $3485.1 \mathrm{~cm}^{-1}$ connotes the presence of $\mathrm{O}-\mathrm{H}$ stretch while the others connote the presence of $\mathrm{C}-\mathrm{H}$ group as is consistent with materials containing high fatty acids content. Incorporation of macrogol into Moringa seed oil revealed loss of the seed oil characteristic sharp peaks at 2922 and $2855 \mathrm{~cm}^{-1}$ which could be an indication of interaction. On the other hand, the major peaks present in Moringa seed oil were observed to be retained when dika fat was incorporated into the seed oil implying the absence of interaction. This justifies the use of dika fat in optimized suppository formulations of Moringa seed oil.

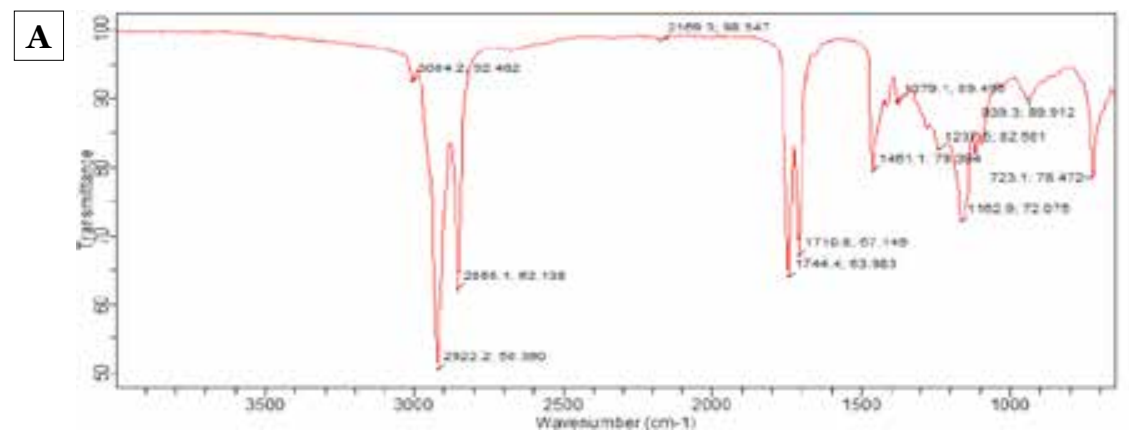



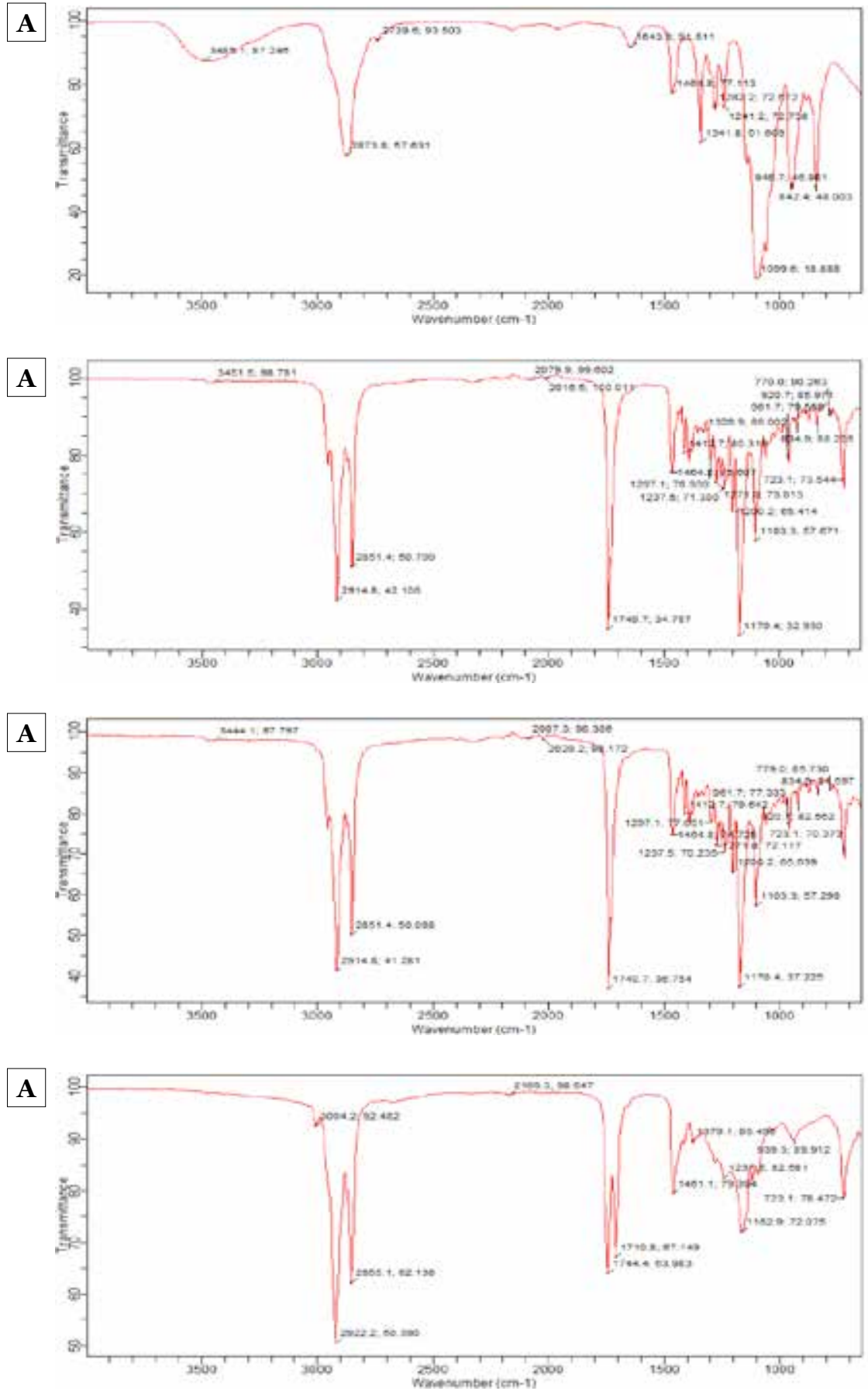

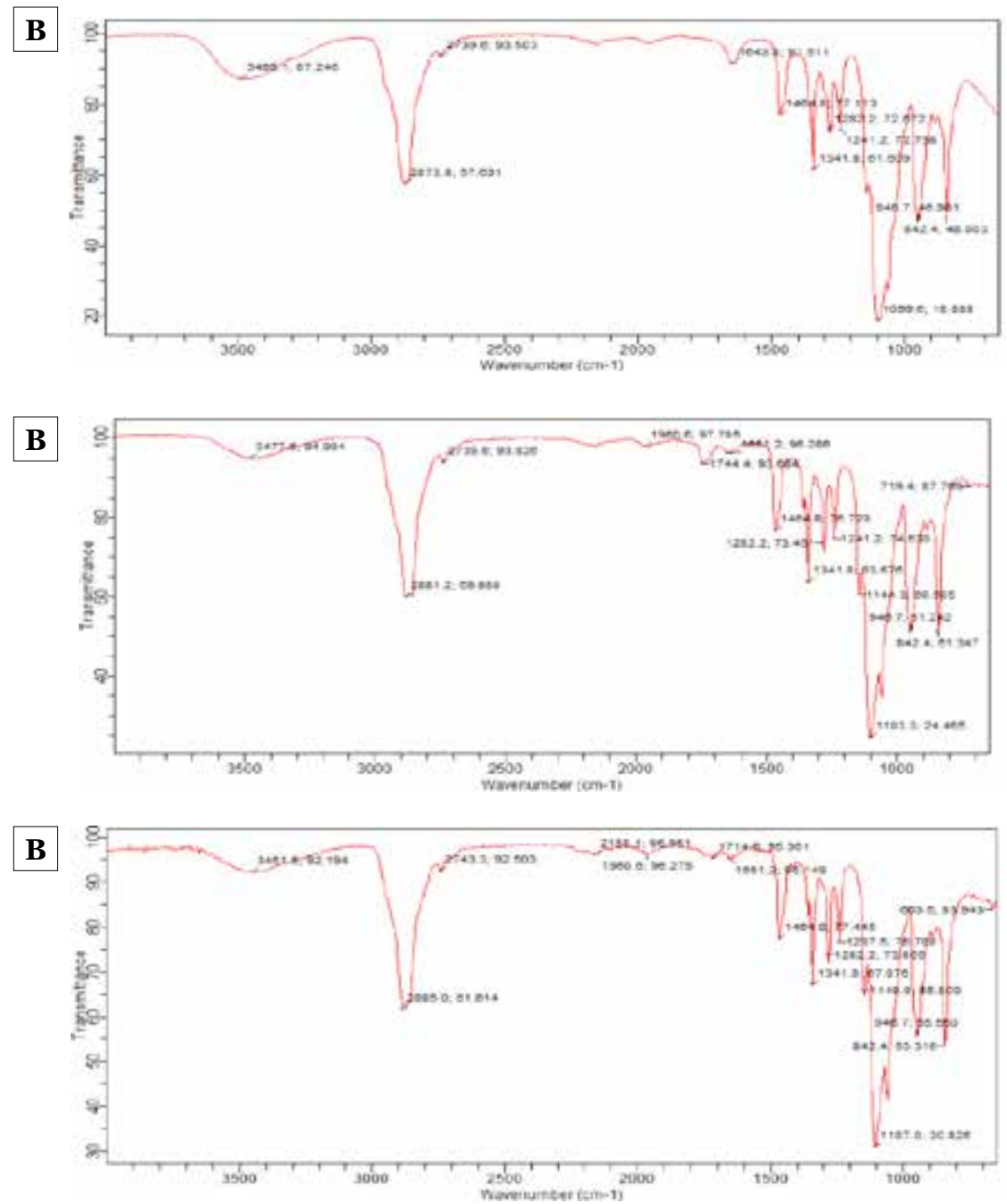

Figure 2. FTIR spectrum of moringa seed oil (A1), dika fat (A2), $5 \% \mathrm{w} / \mathrm{w}$ moringa seed oil+dika fat (A3), $10 \% \mathrm{w} / \mathrm{w}$ moringa seed oil+dika fat (A4), macrogol (B2), $5 \% \mathrm{w} / \mathrm{w}$ moringa seed oil+macrogol (B3), $10 \%$ w/w moringa seed oil+macrogol (B4).

GC-MS analysis of Moringa seed oil showed the presence of various compounds with 9-Octadecenoic acid (56.98\%) being more abundant compared to other compounds. 9-Octadecenoic acid has been found to inhibit production of inflammatory agents in RAW 264.7 cells. The compound had an inhibitory effect on nitric oxide and other inflammatory cytokines such as TNF- $\alpha$, IL-6 (Kang et al., 2018). Another fatty acid found in the GC-MS analysis of seed oil is n-Hexadecanoic acid which through enzyme kinetics study is known to inhibit Phospholipase A(2) which is involved in initiating inflammation (Aparna et al., 2012). 


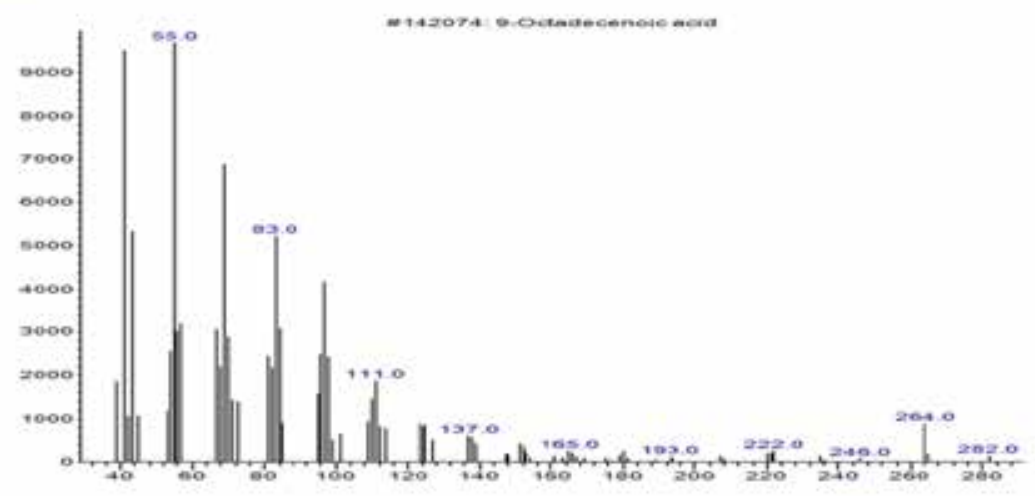

Figure 3. Gas chromatography spectrum of Moringa seed oil

Application of the inducing agent to the recto-anal region of rats caused significant increase in the recto-anal coefficient when compared to the sham group. Administration of suppositories prepared with dika fat (MSD1 and MSD2) caused a significant ( $\mathrm{p}<0.05)$, dose dependent reduction of the RAC at $2.26 \pm 0.17$ and $2.05 \pm 0.38$ when compared with control of $3.50 \pm 0.30$. (Table 3 ). Symptomatic hemorrhoids occur when the integrity of the supporting tissues of the recto-anal region deteriorates; the condition is characterized by vasodilatation, inflammation reaction, haemorrhage, thrombosis and necrosis of vascular tissues in the recto-anal region (Sun \& Migaly, 2016; Faujdar, Sati, Sharma, Pathak, \& Paliwal, 2019). Croton-oil is widely used to induce experimental hemorrhoids in laboratory animals. Treatment with suppositories prepared with Moringa seed oil caused a reduction of the RAC which is an indication of the reduction of inflammation. In other studies, Moringa seed extract has also been shown to demonstrate anti-inflammatory activity in gastric and other tissues (Suryadevara et al., 2018; Minaiyan et al., 2014).

Histological examination showed the tissues of the recto-anal region in control rats presented with haemorrhage, infiltration of inflammatory cells, glandular hardening and necrosis. However, treatment with the suppositories caused an amelioration of tissue injury caused by croton oil. This is observed as reduction of the severity of damage caused to the tissues. Tissues of the recto-anal region in the sham group (group 1) showed normal features, whereas the control (group 2) presented with moderate haemorrhage with infiltration of inflammatory cells and glandular necrosis. Slight glandular hardening necrosis was observed with MSDo containing no Moringa seed oil (group 3), while the groups treated with MSD1 showed infiltration of inflammatory cells with secretory glands hypertrophy (group 4) and those treated with MSD2 (group 5) presented slight hae- 
morrhage and infiltration of inflammatory cells (Figure 4). The biological activity of plant products may be attributed to the component phytochemical compounds as reported by Azeemuddin et al. (2014) and Shivani, Vjayabhaskar, Rao, Kumar, \& Yadav (2019) who recorded reduction of RAC and repair of gastric tissues on administration of plant products on croton oil induced hemorrhoids.

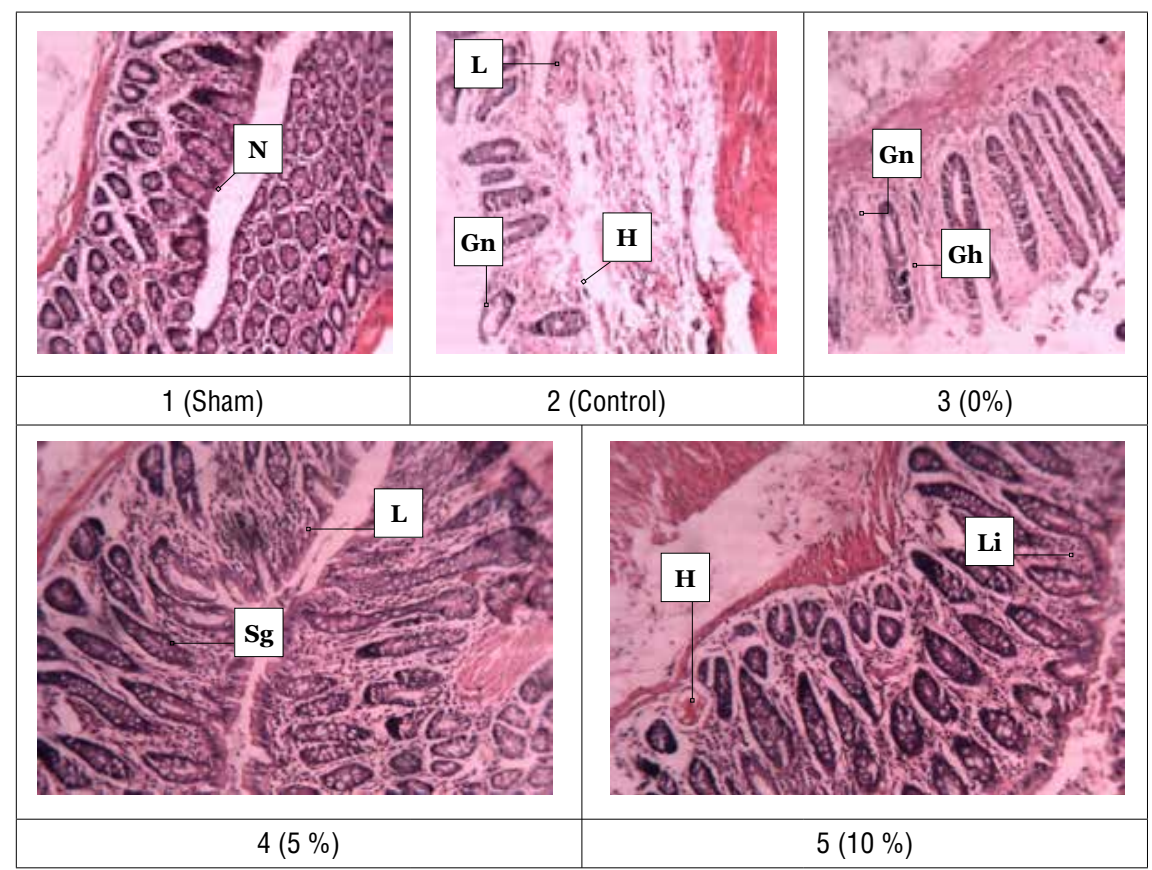

Figure 4. Effects of Moringa oil suppository on croton oil induced haemorrhoids in Wistar rats.

Li - lymphocyte infiltration, N - normal, H - hemorrhage, SG - normal gland, Gn - Glandular necrosis, GH - glandular hardening

In this study, Moringa seed oil suppositories formulated with macrogol and dika fat exhibited good physicochemical characteristics. In vivo anti-inflammatory activity of the optimized formulation show the potential of dika fat as a suppository base for the delivery of Moringa seed oil in the treatment/management of anorectal conditions like hemorrhoids.

\section{AUTHOR CONTRIBUTIONS}

Design- Christianah Y. Isimi

Acquisition of data- Lucy B. John-Africa, Kokonne E. Ekere, Olubunmi J. Olayemi 
Analysis of data- Christianah Y. Isimi, Lucy B. John-Africa, Kokonne E. Ekere, Olubunmi J. Olayemi

Drafting of the manuscript-Christianah Y. Isimi, Lucy B. John-Africa, Kokonne E. Ekere

Critical revision of the manuscript- Olubunmi J. Olayemi, Olusola I. Aremu, Martins O. Emeje

Statistical analysis- Lucy B. John-Africa

Supervision- Christianah Y. Isimi

\section{CONFLICT OF INTEREST}

Authors declare that there is no actual or potential conflict of interest with respect to this article.

\section{ACKNOWLEDGEMENT}

The authors are grateful to Mr Solomon Fidelis of Pharmacology and Toxicology department for his technical support.

\section{ABBREVIATIONS USED}

MSO-Moringa seed oil

DF-dika fat

MG-macrogol

FTIR-Fourier transform infrared spectroscopy

GC-MS-Gas chromatography-mass spectrometry

NIPRD-National Institute for Pharmaceutical Research and Development

HLB-Hydrophilic-Lipophilic Balance

MSMo-macrogol base alone

MSM1-5 \%w/w Moringa seed oil + macrogol base

MSM2-10 \%w/w Moringa seed oil + macrogol base

MSDo- dika fat base alone

MSD1-5\%w/w Moringa seed oil + dika fat base

MSD2-10 \%w/w Moringa seed oil + dika fat base 


\section{REFERENCES}

1. Adebayo, A. S., Akala, E. O. (2005). Kinetics model for the in vitro release of an hydrophilic drug

2. (Amodiaquine) from fat-based Suppositories. Journal of Arts, Science and Technology, 2, 1-11.

3. Amrutia, J. N., Lala, M., Srinivasa, U., Shabaraya, A. R., Moses, R. S. (2011). Anticonvulsant Activity of Moringa oleifera Leaf. International Research Journal of Pharmacy, 2(7), 160-162. 4. Aparna, V., Dileep, K. V., Mandal, P. K., Karthe, P., Sadasivan, C., Haridas, M. (2012). Anti-

a. inflammatory property of n-hexadecanoic acid: structural evidence and kinetic assessment. Chemical Biology \& Drug Design, 80(3), 434-439. doi: 10.1111/j.1747-0285.2012.01418.x

5. Aremu, O. I., Ekere, K. E., Isimi, C. Y., Nwaogu, V. C., Agbaje, O. G., Olayemi, O. J., Adedokun, 6. M. O., Emeje, M. O. (2019). Formulation and Evaluation of Neem (Azadirachta indica A. Juss) Seed Oil Suppositories. Journal of Reports in Pharmaceutical Sciences, 8(2), 245-252. doi: 10.4103/jrptps.JRPTPS_16_19

7. Azeemuddin, M., Viswanatha, G. L., Rafiq, M., Thippeswamy, A. H., Baig, M. R., Kavya, K. J., a. Patki, S., Shyam, R. (2014). An Improved Experimental Model of Haemorrhoids in Rats: Evaluation of Antihaemorrhoidal Activity of an Herbal Formulation. International Scholarly Research Notices Pharmacology, 2014, 1-7. doi: 10.1155/2014/530931

8. British Pharmacopoeia. (2013). British Pharmacopoeia Office: MHRA, 151 Buckingham Palace A road, London SW1W9SZ.

9. CIOMS/ICLAS. (2012). International Guiding Principles for Biomedical Research Involving 10. Animals. Council for International Organization of ethical Sciences/The International Council for Laboratory Animal Science.

11. Efeovbokhan, V. E., Hymore, F. K., Raj, D., Sanni, G. (2015). Alternative Solvents for Moringa a. Seed Extraction. Journal of Applied Sciences, 15(8), 1073-1082. doi: 10.3923/ jas.2015.1073.1082

12. Eman, N. A., Muhamad, K. N. (2016). Comparison of Moringa Seed Oil Characterization Produced

13. Chemically and Mechanically. IOP Conference Series: Earth and Environmental Science, 36 , 1-7. doi: 10.1088/1755-1315/36/1/012063

14. Eshghi, F., Hosseinimehr, S. J., Rahmani, N., Khademloo, M., Norozi, M. S., Hojati, O. (2010).

15. Effect of Aloe vera cream on posthemorrhoidectomy pain and wound healing: Results of a Randomized, Blind, Placebo-Control Study. Journal of Alternative and Complementary Medicine, 16(6), 647-650. doi: 10.1089/acm.2009.0428

16. Evbuomwan, B. O., Dick, D. T., Chioma, A. C. (2017). Comparative Analysis of Effect of Alternative Solvent on Extraction of Moringa Oleifera Seed Oil. Chemistry Research Journal, 2(5), 44-50.

17. Fahey, J. W. (2005). Moringa oleifera: A Review of the Medical Evidence for Its Nutritional, Therapeutical and Prophylactic Properties. Trees for Life Journal, 1(5). doi: 10.1201/9781420039078.ch12

18. Faujdar, S., Sati, B., Sharma, S., Pathak, A. K., Paliwal, S. K. (2019). Phytochemical evaluation 
19. and anti-hemorrhoidal activity of bark of Acacia ferruginea DC. Journal of Traditional and Complementary Medicine, 9(2), 85-89. doi: 10.1016/j.jtcme.2018.02.003

20. Goodman, D. (2001). Pharmacokinetics: Disposition and Metabolism of Drugs. Principles of 21. Pharmacology. New York: Chapman \& Hall.

22. Gupta, R., Mathur, M., Bajaj, V. K., Katariya, P.,Yadav, S., Kamal, R., Gupta, R. S. (2012). Evaluation of antidiabetic and antioxidant activity of Moringa oleifera in experimental diabetes. Journal of Diabetes, 4(2), 164-171. doi: 10.1111/j.1753-0407.2011.00173.x

23. Hamidpour, R., Rashan, L. (2017). An Herbal Remedy with Potent Anti-inflammatory and a. Analgesic Properties. Translational Biomedicine, 8(3), 1-2. doi: 10.21767/2172-0479.100121 24. Kang, M., Ham, Y., Heo, S., Yoon, S., Cho, S., Kwon, S., Jeong, M. S., Jeon, Y., Sanjeewa, K. K. a. A., Yoon, W., Kim, K. (2018). Anti-inflammation effects of 8-oxo-9-octadecenoic acid isolated from Undaria peterseniana in lipopolysaccharide-stimulated macrophage cells. Experimental and Clinical Sciences Journal, 17, 775-783. doi: 10.17179/excli2018-1422

25. Kauss, T., Gaubert, A., Boyer, C., Ba, B. B., Manse, M., Massip, S., Léger, J., Fawaz, F., Lembege,

26. M., Boiron, J., Lafarge, X., Lindegardh, N., White, N. J., Olliaro, P., Millet, P., Gaudin, K. (2013). Pharmaceutical development and optimization of azithromycin suppository for paediatric use. International Journal of Pharmaceutics, 441(1-2), 218-226. doi: 10.1016/j. ijpharm.2012.11.040

27. Lalas, S., Tsaknis, J. (2002). Characterization of Moringa Oleifera Seed Oil Variety "Periyakulam

28. 1". Journal of Food Composition and Analysis, 15(1), 65-77. doi: 10.1006/jfca.2001.1042

29. Minaiyan, M., Asghari, G., Taheri, D., Saeidi, M., Nasr-Esfahani, S. (2014). Anti-inflammatory effect of Moringa oleifera Lam. seeds on acetic acid-induced acute colitis in rats. Avicenna Journal of Phytomedicine, 4(2), 127-136.

30. Mishral, G., Singh, P., Verma, R., Kumar, S., Srivastav, S., Jha, K. K., Khosa, R. L. (2011). Traditional Uses, Phytochemistry and Pharmacological Uses of Moringa oleifera Plant: An Overview. Der Pharmacia Lettre, 3(2), 141-164.

31. Mosbah, A. E., Mokhtar, E. (2016). Formulation and Evaluation of Ibuprofen Suppositories. International Reserach Journal of Pharmacy, 76), 87-90. doi: 10.7897/2230-8407.07670

32. Nishiki, K., Nishinaga, K., Kudoh, D., Iwai K. (1988). Croton oil-induced haemorrhoid model in rat: comparison of anti-inflammatory activity of diflucortolone valerate with other glucocorticoid. Nihon Yakurigaku Zasshi, 92(4), 215-225. doi: 10.1254/fpj.92.215

33. Ogunsina, B. S., Indira, T. N., Bhatnagar, A. S., Radha, C., Debnath, S., Krishna, A.G. (2014). Quality Characteristics and Stability of Moringa Oleifera Seed Oil of Indian Origin. Journal of Food Science and Technology, 51(3), 503-510. doi: 10.1007/s13197-011-0519-5

34. Okhale, S. E., Ugbabe, G. E., Oladosu, P. O., Ibrahim, J. A., Egharevba, H. O., Kunle, O. F., Elisha, E. P., Chibuike, A. J., Ettah, U. O. (2018). Chemical constituents and antimicrobial activity 35. of the leaf essential oil of Ixora coccinea L. (Rubiaceae) collected from North Central Nigeria. International Journal of Bioassays, 7.5, 5630-5637. doi: 10.21746/ijbio.2018.7.5.1

36. Olaleye, O. O., Kukwa, R. E. (2018). Physicochemical Properties and Chemical Constituent

a. Characterization of Moringa oleifera Seed Oil from Benue State, Nigeria, Extracted Using Cold and Soxhlet Method. International Research Journal of Pure and Applied Chemistry, 
16(3), 1-11. doi: 10.9734/IRJPAC/2018/40938

37. Perry, K. R. (2019). Hemorrhoids. Retrieved from https://emedicine.medscape.com/ article/775407-overview

38. Rastogi, T., Bhutda, V., Moon, K., Aswar, P. (2009). Comparative Studies on Anthelminthic

39. Activity of Moringa oleifera and Vitex Negundo. Asian Journal of Research Chemistry, 2(2), 181-182.

40. Saini, R. K., Sivanesan, I., Keum, Y. (2016). Phytochemicals of Moringa oleifera: A Review of Their Nutritional, Therapeutic and Industrial Significance. 3 Biotech. 6(2), 203. doi: 10.1007/ s13205-016-0526-3

41. Shivani, T., Vijayabhaskar, K., Rao, P. S., Kumar, B. A., Yadav, K. (2019). Anti- hemorrhoidal activity of leaf butanol fraction Portulaca oleracea L., belonging to the family Portulacaceae. IOSR Journal of Pharmacy and Biological Sciences, 14(5), 16-20. doi: 10.9790/30081405031620

42. Siyanbola, T. O., Edobor-Osoh, A., Ajanaku, C. O., Akinsiku, A. A., Adedapo, E. A., Aladesuyi, O., Olanrewaju, I. O., Jokotagba, O. A. (2015). Nutritional and Physico-Chemical Evaluations of Moringa oleifera Seedlings and Oil. Journal of the International Association of Advanced Technology and Science, 1(1), 1-5.

43. Somnath, V., Veena, K., Prakash, K., Sanjay, K., Shruti, R., Vishral, P. (2015). Design and a. characterization of Moringa oleifera seed oil impregnated anti-inflammatory topical dispersion. Der Pharmacia Lettre, 7(3), 7-16.

44. Sun, Z., Migaly, J. (2016). Review of Hemorrhoid Disease: Presentation and Management. Clinics

45. in Colon and Rectal Surgery, 29(1), 22-29. doi: 10.1055/s-0035-1568144

46. Suryadevara, V., Doppalapudi, S., Sasidhar, R., Anne, R., Mudda, M. (2018). Formulation and

47. evaluation of anti-inflammatory cream by using Moringa oleifera seed oil. Pharmacognosy Research, 1O(2), 195-204. doi: 10.4103/pr.pr_101_17

48. Taha, E. I., Zaghloul, A. A., Kassem, N. A. (2003). Salbutamol Sulphate Suppositories: Influence

a. of Formulation on Physical Parameters and Stability. Pharmaceutical development and technology, 8(1), 21-30. doi: 10.1081/pdt-120017520. 